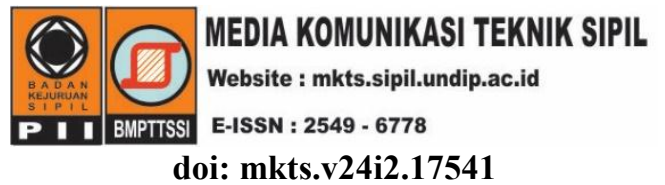

\title{
Evaluasi Tingkat Akurasi Digital Elevation Model (DEM) SRTM dan ASTER GDEM dalam Pemodelan Daerah Aliran Sungai (DAS) Ciliwung
}

\author{
*Ade Suhendar Sutisna, Haryono Putro \\ Jurusan Teknik Sipil, Universitas Gunadarma Depok, Jawa Barat \\ ${ }^{*}$ Adesuhendarsutisna@gmail.com
}

Received: 6 Februari 2018 Revised: 19 September 2018 Accepted: 21 September 2018

\begin{abstract}
Availability of Digital Elevation Model (DEM) dataset and Geographic Information System (GIS), makes the watershed properties can be extracted automatically. There are two DEM providers which are freely accessible for research purposes and commonly use that is the Shuttle Radar Topographic Mission (SRTM) DEM (30m) and Advanced Spaceborne Thermal Emission and Reflection Radiometer (ASTER) Global Digital Elevation Model Version 2 (GDEM V2). Based on the result of modeling conducted at Ciliwung River Basin with Qgis application, area generated from SRTM data is 5\% smaller than Ciliwung River Basin which obtained from BPDAS Ciliwung-Citarum as a reference, while the result of ASTER-GDEM data is $87 \%$ larger than reference. Linear Regression Test and $t$-Test performed on three segments of the watershed shows that the upstream of both samples gives a good accuracy result that is $R^{2}=0,999 ; P=0,499$ (SRTM) and $R^{2}=0,999 ; P=0,481$ (ASTER-GDEM), while in the middle and downstream segments respectively for both samples are SRTM with $R^{2}=0,993 ; P=0,413$ and $R^{2}=0,734 ; P=0,088$; and then ASTER-GDEM with $R^{2}=0,784 ; P=0,00038$ and $R^{2}=0,376 ; P=1,27209 \times 10^{-22}$.
\end{abstract}

Keyword: Watershed, DEM, modeling, SRTM, ASTER-GDEM

\begin{abstract}
Abstrak
Tersedianya data Digital Elevation Model (DEM) dan Sistem Informasi Geografis (SIG), membuat sifat DAS dapat diekstraksi secara otomatis. Terdapat dua penyedia DEM yang dapat diakses secara bebas untuk kepentingan penelitian dan biasa digunakan yaitu Shuttle Radar Topographic Mission (SRTM) - DEM (30m) dan Advanced Spaceborne Thermal Emission and Reflection Radiometer (ASTER) Global Digital Elevation Model Version 2 (GDEM V2). Berdasarkan hasil pemodelan yang dilakukan pada Daerah Aliran Sungai (DAS) Ciliwung dengan aplikasi Qgis diperoleh luasan hasil modeling dengan data SRTM sebesar 5\% lebih kecil dibandingkan batas DAS Ciliwung yang diperoleh dari BPDAS Ciliwung-Citarum sebagai acuan, sedangkan hasil modeling dengan data ASTER-GDEM menghasilkan luasan sebesar $87 \%$ lebih besar dari acuan. Uji Regresi Linier dan t-Test yang dilakukan pada tiga segmen DAS menunjukkan pada bagian hulu kedua sampel memberikan hasil akurasi yang sangat baik yaitu $R^{2}=0,999 ; P=0,499($ SRTM $)$ dan $R^{2}=$ 0,999; $P=0,481$ (ASTER-GDEM), sedangkan pada segmen tengah dan hilir secara berturut-turut untuk kedua sampel adalah SRTM dengan $R^{2}=0,993 ; P=0,413$ dan $R^{2}=0,734 ; P=0,088$, kemudian ASTERGDEM dengan $R^{2}=0,784 ; P=0,00038$ dan $R^{2}=0,376 ; P=1,27209 \times 10^{-22}$.
\end{abstract}

Kata Kunci: DAS, DEM, pemodelan, SRTM, ASTER-GDEM

\section{Pendahuluan}

Kejadian banjir yang sering terjadi terutama di daerah perkotaan saat ini telah menyebabkan kerugian yang cukup besar bagi masyarakat. Salah satu langkah yang dilakukan untuk mengurangi dampak akibat kejadian ini adalah dengan melakukan pemodelan daerah genangan banjir. Pemodelan ini dilakukan untuk mengetahui prediksi lokasi dan luas daerah yang akan terdampak ketika banjir terjadi. Pada umumnya pemodelan dilakukan dengan menggunakan data 
digital elevation model (DEM) untuk menentukan lokasi dan luas genangan yang terjadi.

Telah banyak penelitian terkait penggunaan data DEM sebagai data analisis genangan banjir, di antaranya adalah penelitian "Digital elevation models and their applications in flood risk management (Bodis, K. 2008)", "Model simulasi luapan banjir Sungai Ciliwung di Wilayah Kampung Melayu-Bukit Duri Jakarta (Yulianto \& Marfai. 2010)", "Pemetaan daerah potensi banjir dengan segmentasi data digital elevation model, studi kasus: DAS Ciliwung di DKI Jakarta (Riyanto \& Sudiana, 2007)", "Application of ASTER GDEM in watersheed management and flood zonation mapping in Koyana River of the western gats (Kumthekar et al., 2013)" dan "Kajian pemanfaatan DEM SRTM dan google earth untuk parameter penilaian potensi kerugian ekonomi akibat banjir rob (Nugraha, 2013)".

Akan tetapi salah satu aspek yang kerap kali dilupakan terkait terjadinya banjir di suatu kota adalah adanya keterkaitan antara banjir dengan kesatuan wilayah yang disebut dengan daerah aliran sungai (DAS). Kawasan DAS merupakan kawasan yang dikelola dalam upaya menjaga kontinuitas ketersediaan air. Air hujan yang terkumpul pada DAS inilah yang mampu menimbulkan banjir yang kerap menjadi permasalahan di daerah perkotaan. Pembuatan jaringan sungai dan batas DAS dengan metode manual menggunakan peta topografi hardcopy memakan waktu yang lama dan biaya yang besar sehingga diperlukan suatu cara agar bisa menghemat waktu dan biaya tersebut. Selain waktu dan biaya yang besar, penentuan jaringan dan batas DAS secara manual juga bersifat subyektif terutama pada daerah hilir.

Diperlukan metode dalam penentuan suatu DAS yang cepat, otomatis dan terintegrasi dengan data DAS lainnya. Pesatnya perkembangan teknologi dan tersedianya model elevasi permukaan bumi digital atau Digital Surface Model (DSM) (dikenal juga dengan istilah Digital Elevation Model) dan Sistem Informasi Geografis (SIG), membuat sifat DAS dapat diekstraksi secara otomatis. Digital Elevation Model (DEM) merupakan representasi digital dari permukaan bumi yang menyimpan informasi ketinggian lahan tersebut. DEM merepresentasikan data ketinggian yang disimpan secara tepat dan dapat digunakan untuk berbagai aplikasi pemetaan seperti GIS. Ketinggian lahan yang terekam di dalam DEM diperoleh dari data citra dan sensor satelit yang berada di angkasa, sehingga mampu meng-cover area yang sangat luas.
Adapun penelitian penggunaan DEM sebagai media pembuatan daerah aliran sungai yang telah dilakukan antara lain "Pour point description of watershed based on DEM of Bilaspur Dsitrict (Manikpuri \& Choundhary. 2013)", "Modelling small watersheds in Brazilian Amazonia with shuttle radar topographic mission-90 $\mathrm{m}$ data (Valeriano et al., 2006)". Data DEM yang umum digunakan pada proses penelitian dan pemodelan adalah data advance spaceborne thermal emission radiometer-global digital elevation model (ASTER GDEM) dan shuttle radar topographic mission (SRTM). Data SRTM dan ASTER GDEM merupakan data topografi yang paling lengkap dan presisi di dunia, yang telah menyediakan sumber terpercaya untuk analisis geografis.

Semenjak data SRTM dan ASTER GDEM dapat diakses secara publik, penilaian akurasi/ kualitasnya telah menjadi fokus studi, termasuk perbandingan DEM dengan DEM yang dihasilkan dari sumber yang berbeda, penggunaan ground crontrol point melalui pengukuran, verifikasi menggunakan LIDAR dan lain-lain. Metode penilaian akurasi DEM yang biasa dilakukan meliputi pengukuran luas daerah genangan, delineasi DAS dan stream network analysis.

Adapun penelitian yang membahas terkait hal ini, di antaranya "Comparison of watershed boundaries derived from SRTM and ASTER digital elevation datasets and from a digitized topographic map (Pryde et al., 2007)", "Sensitivity of coastal flood risk managements of digital elevation models (Sande et al., 2012)", "Vertical accuracy assessment of SRTM and ASTER GDEM over coastal regions of China: A comparative analysis (Du et al., 2012)". "Evaluation of ASTER GDEM 2 in comparison with GGDEM 1, SRTM DEM and topographicmap-derived DEM using inundation area analysis and RTK-dGPS data (Suwandana et al., 2012)", dan "Assesing the quality of digital elevation models obtained from mini unmanned aerial vehicles for overland flow modelling in urban areas (Leitão et al., 2016). Dengan melihat hal-hal tersebut, dirasa perlu adanya penelitian terkait dengan validitas dan akurasi data DEM khusunya pada wilayah Indonesia terutama pada DAS Ciliwung yang masuk ke dalam kategori 15 DAS prioritas beradasarkan data dari Kementrian Lingkungan Hidup.

\section{Metode Penelitian}

Secara keseluruhan, proses penelitian digambarkan pada Gambar 1. 


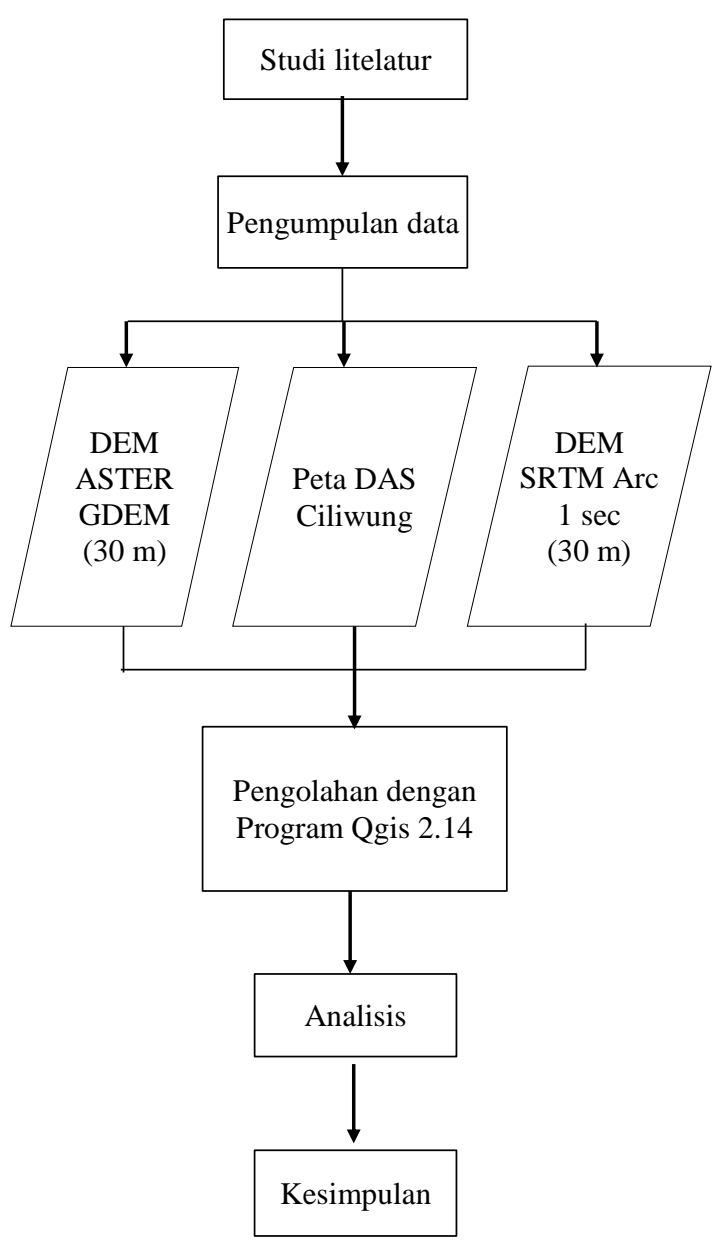

Gambar 1. Bagan alur penelitian

\section{Inventarisasi data}

Data yang digunakan dalam penelitian ini antara lain: (1) Data DEM SRTM resolusi $30 \mathrm{~m}$ yang diunduh dari situs USGS dalam format tiff. (2) Data DEM ASTER GDEM resolusi $30 \mathrm{~m}$ yang diunduh dari situs USGS dalam format .tiff. (3) Peta DAS Ciliwung yang diperoleh dari Badan Pengelola Daerah Aliran Sungai (BPDAS) Ciliwung - Citarum hasil pengolahan data Peta RBI (BIG), DEM (LAPAN), dan data lapangan, sesuai Peraturan Menteri Kehutanan Republik Indonesia No. P.59/Menhut-II/2013. Sedangkan peralatan atau tools yang dipergunakan adalah Qgis 2.14 dan Microsoft Excel.

\section{Pemodelan}

Langkah-langkah pemodelan DAS menggunakan data DEM dilakukan dengan mengikuti panduan Exercise open source software for preprocessing GIS data for hydrological models (van de Kwast, 2017).

\section{Analisis statistik}

Proses analisis dilaksanakan dengan metode uji statistik, melalui metode regresi linier dan pengujian t-Test. Hal ini dilakukan untuk mengetahui hubungan antara model yang dihasilkan dengan acuan dan tingkat perbedaannya...

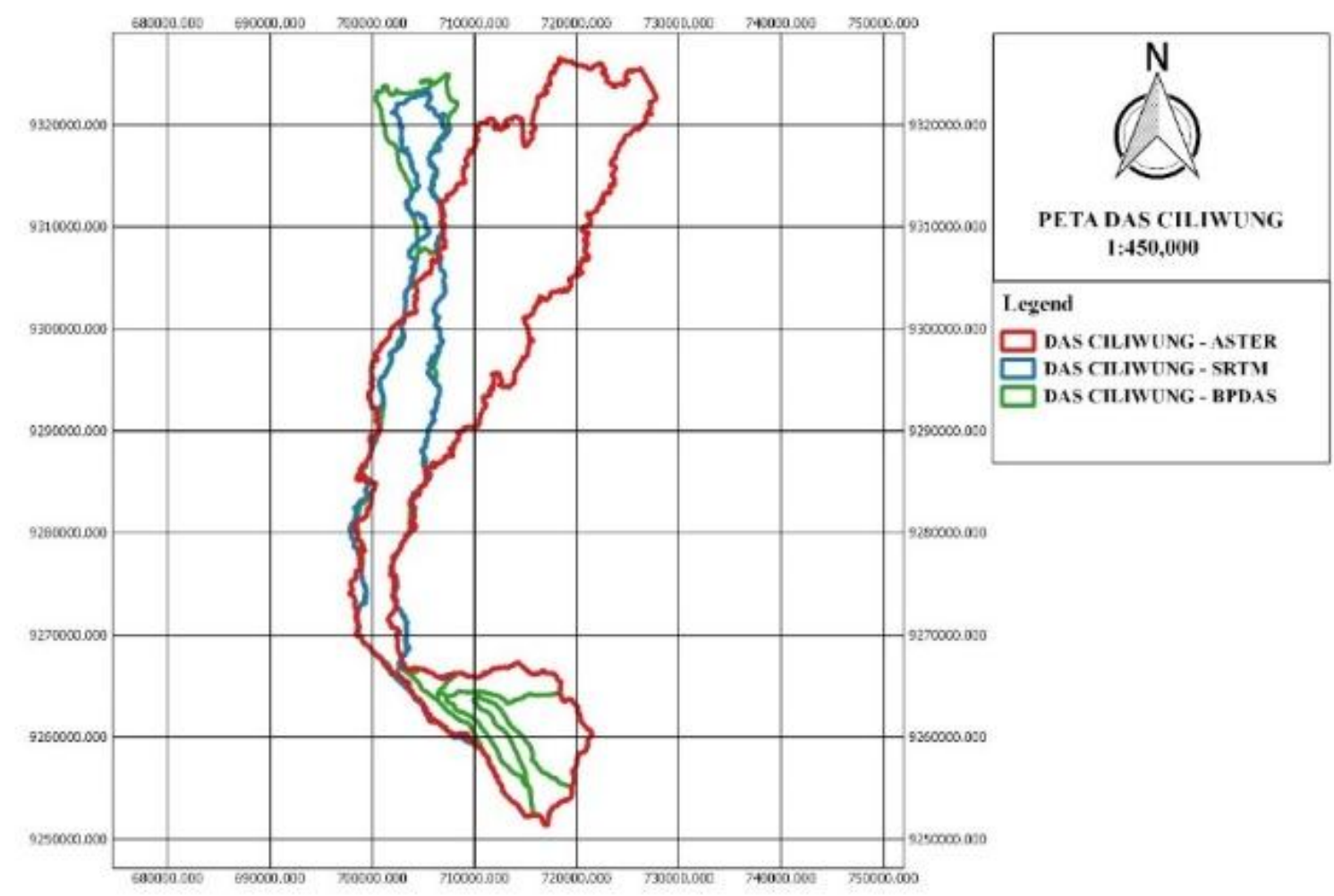

Gambar 2. Peta DAS hasil pemodelan 


\section{Hasil dan Pembahasan}

Berdasarkan hasil pemodelan dengan program Qgis 2.14 menggunakan data DEM SRTM dan ASTER-GDEM, diperoleh hasil sebagaimana ditunjukan pada Gambar 2.

Hasil pemetaan tersebut kemudian dibandingkan dengan peta DAS Ciliwung yang diperoleh dari BPDAS Ciliwung-Citarum sebagai acuan dasar. Parameter yang dibandingkan pertama kali adalah luasan dari masing-masing DAS. Luas DAS Ciliwung berdasarkan peta dari BDAS adalah seluas 38.610,25 ha, dan luas yang diperoleh dari hasil modeling SRTM adalah 36.762,16 ha atau $5 \%$ lebih kecil, sedangkan hasil modeling dengan ASTER-GDEM menghasilkan luasan sebesar $72.287,21$ ha atau $87 \%$ lebih besar dibandingkan dengan peta DAS Ciliwung yang diperoleh dari BPDAS.
Proses evaluasi selanjutnya dilakukan dengan menggunakan koordinat kartesius untuk mengetahui nilai absis $\mathrm{X}$ untuk satu nilai ordinat $\mathrm{Y}$ yang sama dari masing-masing peta dengan interval ordinat $500 \mathrm{~m}$. Berdasarkan hasil tersebut dilakukan uji statistik dengan uji regresi linier dan T-Test untuk mengetahui tingkat perbedaan dari masing-masing data. Adapun hasil uji regresi linier yang telah dilakukan dapat dilihat pada Tabel 1 berikut.

Tabel 1. Hasil uji regresi linier

\begin{tabular}{lrr}
\hline Regression statistics & SRTM & \multicolumn{1}{c}{ ASTER } \\
\hline Multiple $R$ & 0,9933 & 0,6835 \\
R square & 0,9866 & 0,4671 \\
Adjusted $R$ square & 0,9866 & 0,4653 \\
Standard error & 676,4863 & $6.171,0781$ \\
Observations & 297,0000 & 297,0000 \\
\hline
\end{tabular}

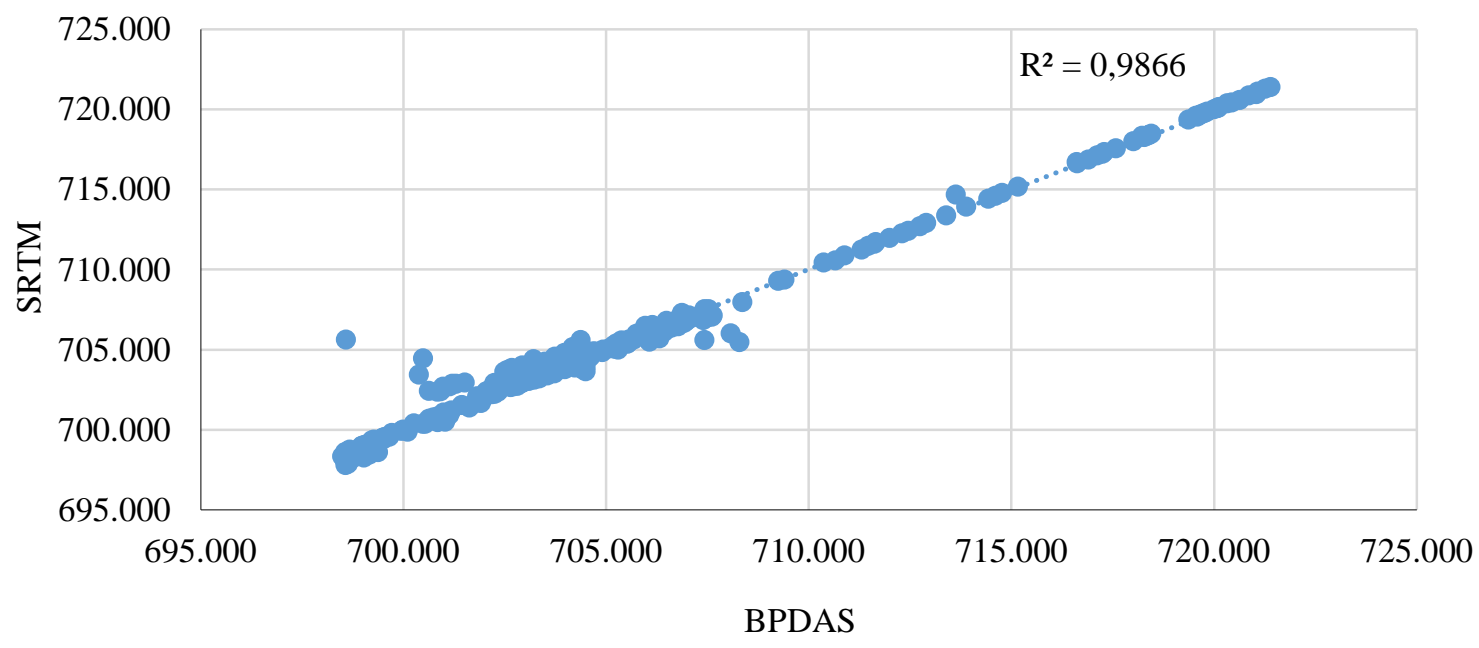

Gambar 3. Regresi linier koordinat X Peta SRTM dan BPDAS

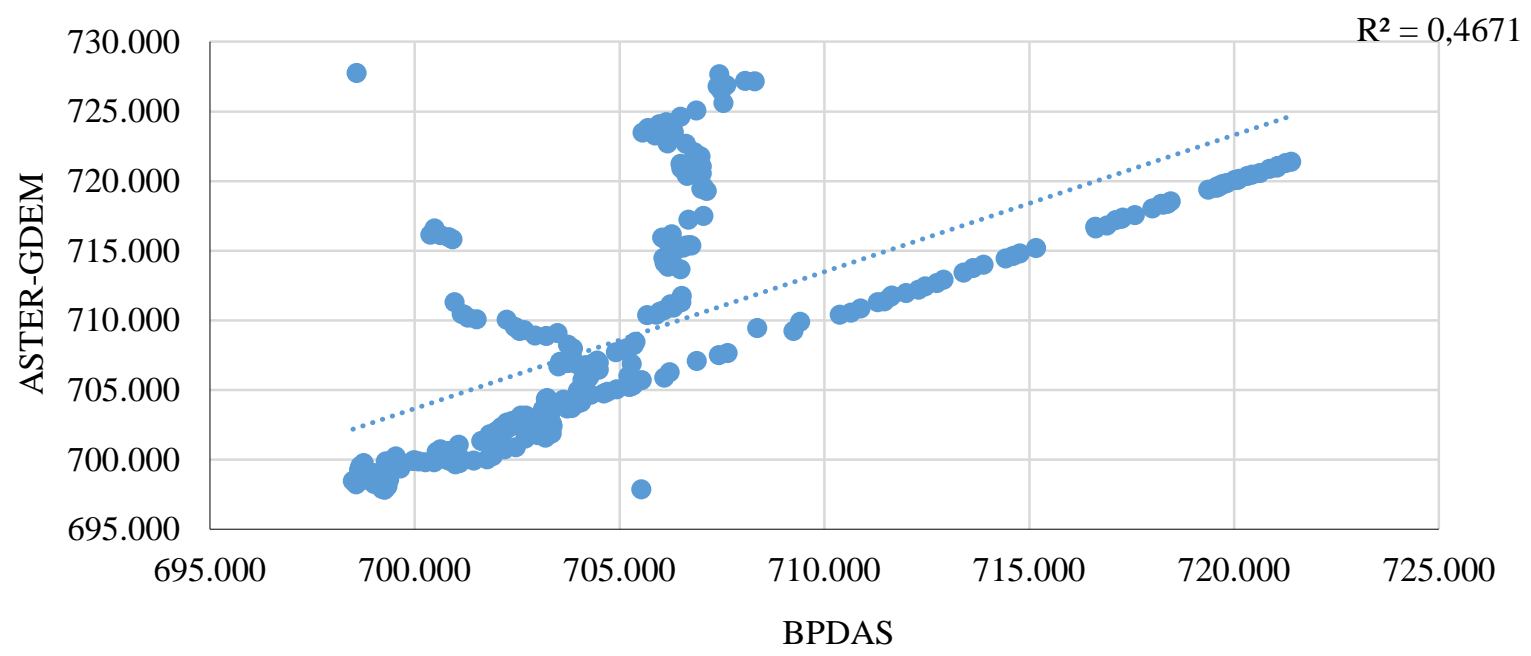

Gambar 4. Regresi linier koordinat X Peta ASTER-GDEM dan BPDAS 
Tabel 2. Hasil uji T-test seluruh sample uji

\begin{tabular}{lrrr}
\hline \multicolumn{1}{c}{ Parameter } & BPDAS & \multicolumn{1}{c}{ SRTM } & \multicolumn{1}{c}{ ASTER } \\
\hline Mean & $705.754,2500$ & $705.819,3900$ & $709.310,8800$ \\
Variance & $34.519 .145,6600$ & $34.099 .943,1500$ & $71.222 .851,5900$ \\
Observations & 297,0000 & 297,0000 & 297,0000 \\
Pooled variance & & $34.309 .544,4000$ & $52.870 .998,6200$ \\
Hypothesized mean difference & 0,0000 & 0,0000 \\
df & 592,0000 & 592,0000 \\
t stat & $-0,1355$ & $-5,9606$ \\
P $(\mathrm{T}<=t)$ one-tail & 0,4464 & 0,0002 \\
t critical one-tail & 1,6470 & 1,6470 \\
\hline
\end{tabular}

Berdasarkan hasil uji T-test yang dilakukan terlihat bahwa untuk sample hasil modeling menggunakan data SRTM tidak terdapat perbedaan signifikan dibanding data acuan (nilai $\mathrm{p}=0,44>\alpha=0,005$, H0 diterima), sedangkan untuk hasil modeling dengan ASTER-GDEM terdapat perbedaan signifikan (nilai $\mathrm{p}=2,15882 \mathrm{E}-09<\alpha=0,005$, H0 ditolak). Sampel uji kemudian dibagi ke dalam tiga segmen, pembagian dilakukan ke dalam segmen Ciliwung Hulu, Ciliwung Tengah dan Ciliwung Hilir, berdasarkan pembagian segmen dari Peta BPDAS Ciliwung. Hasil uji regresi linier untuk masing-masing segmen dapat dilihat pada Tabel 3 sampai 5.

Tabel 3. Rekapitulasi parameter statistik regresi linier segmen Ciliwung Hulu

\begin{tabular}{lrr}
\hline Parameter & SRTM & ASTER \\
\hline Multiple $R$ & 0,100 & 0,100 \\
R square & 0,100 & 0,100 \\
Standar error & 156,668 & 179,521 \\
Observations & 75,000 & 75,000 \\
\hline
\end{tabular}

Berdasarkan hasil Tabel 3 di atas dapat dilihat bahwa pada segmen Ciliwung Hulu, nilai korelasi (R) dari masing-masing data set menunjukkan hasil yang baik. Hal ini ditunjukan dengan nilai $\mathrm{R}$ yang mendekati nilai 1, yang menunjukkan bahwa hubungan antara masing-masing data set dengan batas DAS dari BPDAS sebagai tolok ukur sangat baik.

Tabel 4. Rekapitulasi parameter statistik regresi linier Segmen Ciliwung Tengah

\begin{tabular}{lrr}
\hline Parameter & \multicolumn{1}{c}{ SRTM } & \multicolumn{1}{c}{ ASTER } \\
\hline Multiple $R$ & 0,9964 & 0,8856 \\
$R$ Square & 0,9928 & 0,7843 \\
Standar Error & 233,4706 & $1.280,5385$ \\
Observations & 160,0000 & 160,0000 \\
\hline
\end{tabular}

Berlanjut ke hasil Tabel 4 di atas dapat dilihat bahwa pada segmen Ciliwung Tengah, nilai korelasi (R) dari masing-masing data set masih menunjukkan hasil yang baik. Akan tetapi mulai terjadi perbedaan yang cukup terlihat jika membandingkan nilai yang dihasilkan masing- masing dataset. Hal ini terutama terlihat pada hasil parameter statistik yang dihasilkan data set ASTER-GDEM, terjadi penurunan yang cukup jauh jika dibandingkan dengan hasil yang diperoleh dari dataset di bagian hulu, dimana pada segmen hulu niali $\mathrm{R}=0,9996$ sedangkan pada segmen tengah menjadi $\mathrm{R}=0,8855$.

Segmen hilir memberikan nilai korelasi paling kecil, sebagaimana terlihat pada Tabel 5 dimana nilai $\mathrm{R}$ yang dihasilkan dari data ASTER-GDEM pada segmen ini turun sangat jauh jika dibandingkan dengan nilai yang diperoleh pada segmen-segmen sebelumnya. Hal ini menunjukkan terjadinya penyimpangan yang cukup besar dari hasil modeling yang diperoleh dari data ASTERGDEM pada segmen hilir. Secara grafis, persebaran data nilai absis ( $\mathrm{x}$ ) masing-masing segmen dapat dilihat pada Gambar 5 sampai dengan 8 .

Tabel 5. Rekapitulasi parameter statistik regresi linier segmen Ciliwung Hilir

\begin{tabular}{lrr}
\hline Parameter & \multicolumn{1}{c}{ SRTM } & \multicolumn{1}{c}{ ASTER } \\
\hline Multiple $R$ & 0,8567 & 0,6136 \\
R square & 0,7340 & 0,3765 \\
Standar error & $1.248,4560$ & $1.911,3188$ \\
Observations & 62,0000 & 62,0000 \\
\hline
\end{tabular}

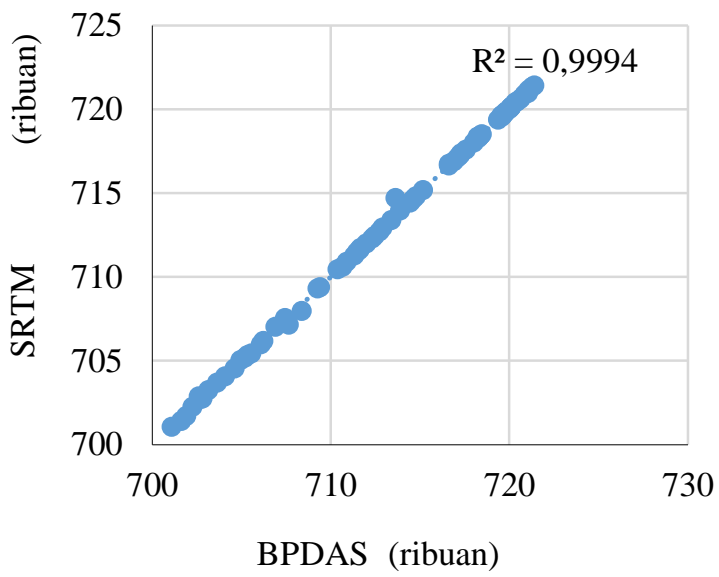

Gambar 5. Regresi linier koordinat X Ciliwung Hulu Peta SRTM dan BPDAS 


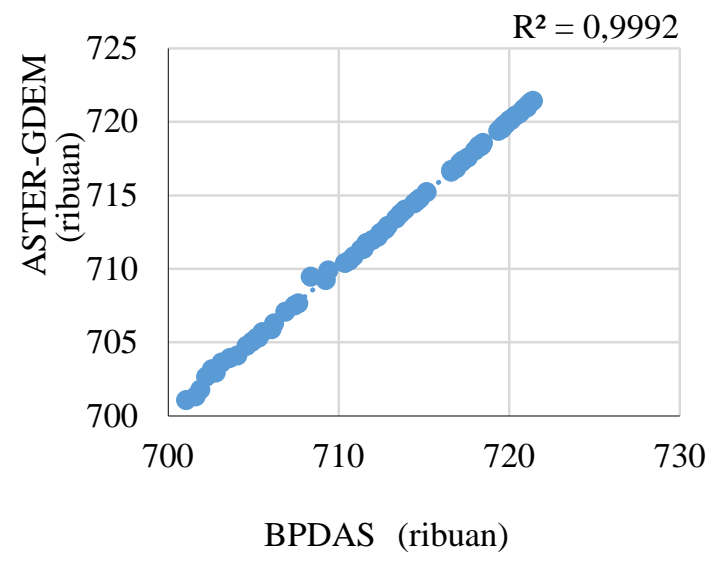

Gambar 6. Regresi linier koordinat X Ciliwung Hulu Peta ASTER-GDEM dan BPDAS

Berdasarkan Gambar 5 dan 6 yang menunjukkan grafik hasil regresi linier koordinat X Ciliwung untuk masing-masing dataset pada segmen hulu, dapat dilihat bahwa sebaran data yang dihasilkan masih berada pada satu garis diagonal yang menunjukkan tidak adanya penyimpangan data yang signifikan.

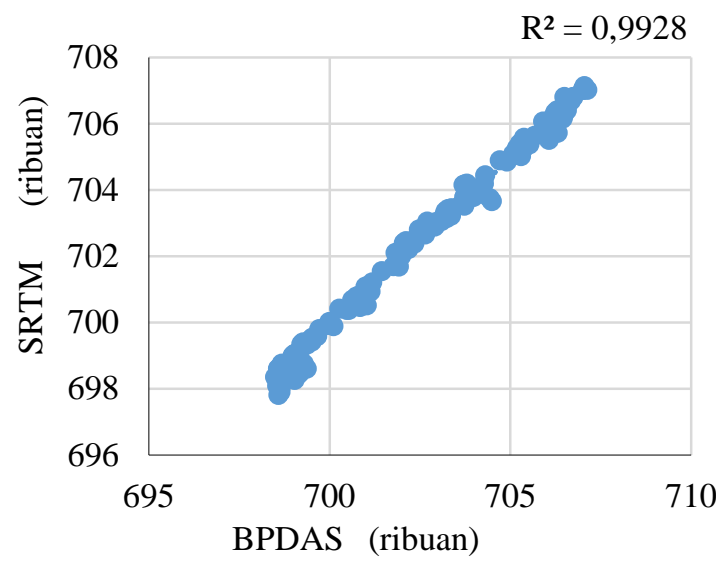

Gambar 7. Regresi linier koordinat X Ciliwung Tengah Peta SRTM dan BPDAS

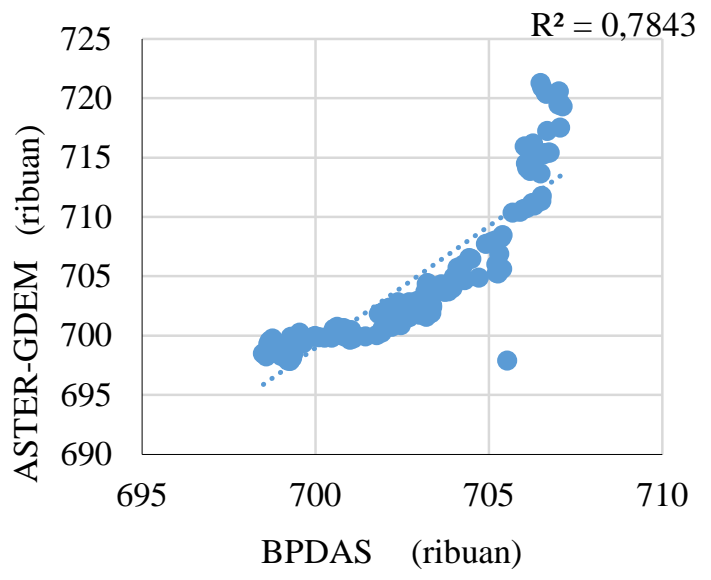

Gambar 8. Regresi linier koordinat X Ciliwung Tengah Peta ASTER-GDEM dan BPDAS
Berdasarkan Gambar 7 dan 8 yang menunjukkan grafik hasil regresi linier koordinat $\mathrm{X}$ Ciliwung untuk masing-masing dataset pada segmen tengah, terlihat mulai adanya penyimpangan pada persebaran data hasil modeling dengan menggunakan data ASTER-GDEM.

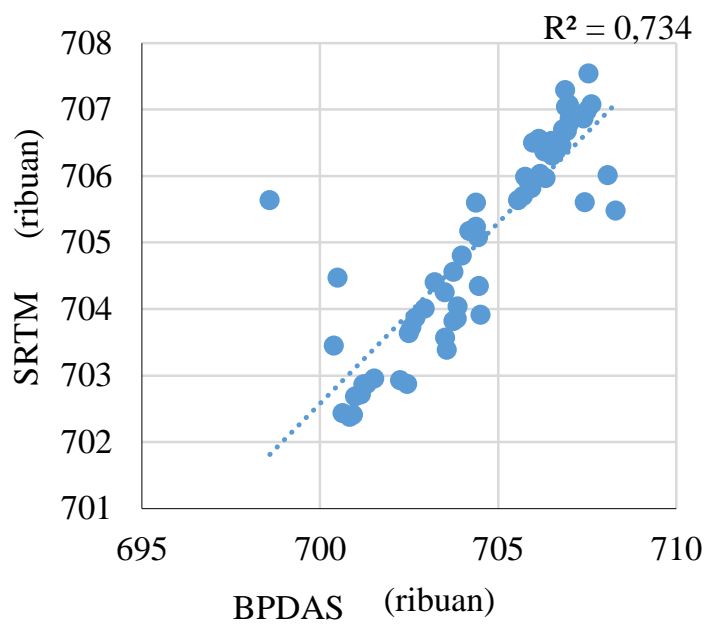

Gambar 9. Regresi linier koordinat X Ciliwung Hilir Peta SRTM dan BPDAS

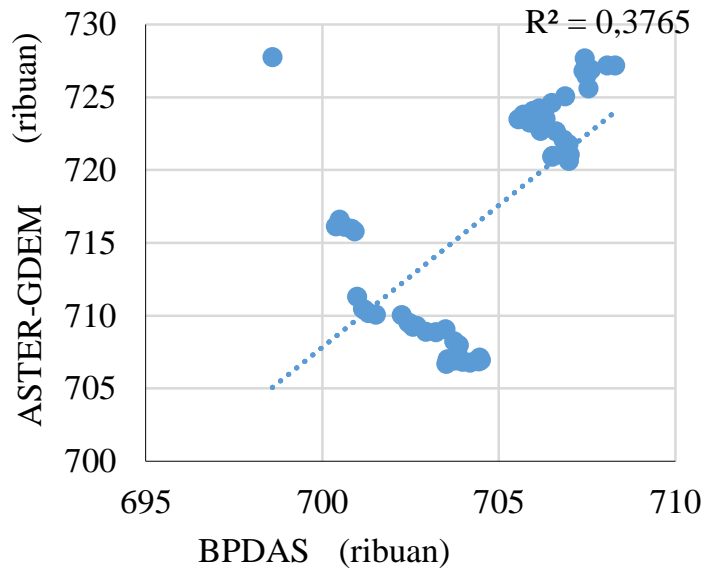

\section{Gambar 10. Regresi linier koordinat X Ciliwung Hilir Peta ASTER-GDEM dan BPDAS}

Berdasarkan Gambar 9 dan 10 yang menunjukkan grafik hasil regresi linier koordinat X Ciliwung untuk masing-masing dataset pada segmen hilir, dapat dilihat bahwa terjadi penyimpangan data yang sangat besar pada segmen hilir. Penyimpangan terbesar ditunjukan oleh grafik data hasil modeling dengan menggunakan data ASTER-GDEM.Adapun hasil uji T-test untuk masing-masing segmen tersaji pada Tabel 6 sampai dengan 8 .

Berdasarkan hasil di atas dapat terlihat bahwa pada bagian hulu yang memiliki tingkat kemiringan lahan tinggi, kedua data set tidak menunjukkan perbedaan yang signifikan antara batas deliniasi 
Tabel 6. Hasil uji T-Test Segmen Ciliwung Hulu

\begin{tabular}{lrrr}
\hline \multicolumn{1}{c}{ Parameter } & BPDAS & \multicolumn{1}{c}{ SRTM } & \multicolumn{1}{c}{ ASTER } \\
\hline Mean & $713.156,7716$ & $713.155,6892$ & $713.207,0884$ \\
Variance & $40.767 .606,6400$ & $41.085 .688,2300$ & \\
Observations & 75,0000 & 75,0000 & 75,0000 \\
Pooled variance & & 40926647,4300 & 40431753,2600 \\
Hypothesized mean difference & 0,0000 & 0,0000 \\
Df & & 148,0000 & 148,0000 \\
$t$ Stat & 0,0010 & $-0,0485$ \\
$P(T<=t)$ one-tail & 0,4996 & 0,4807 \\
$t$ Critical one-tail & 1,6552 & 1,6552 \\
\hline
\end{tabular}

Tabel 7. Hasil uji T-Test Segmen Ciliwung Tengah

\begin{tabular}{lrrr}
\hline \multicolumn{1}{c}{ Parameter } & \multicolumn{1}{c}{ BPDAS } & \multicolumn{1}{c}{ SRTM } & \multicolumn{1}{c}{ ASTER } \\
\hline Mean & $702.741,348$ & $702.672,596$ & $704.605,943$ \\
Variance & $7.552 .593,757$ & $7.897 .715,413$ & $40.628 .620,390$ \\
Observations & 160,000 & 160,000 & 160,000 \\
Pooled variance & & $7.725 .154,585$ & $24.090 .607,080$ \\
Hypothesized mean difference & & 0,000 & 0,000 \\
df & & 318,000 & 318,000 \\
$t$ Stat & & 0,221 & $-3,398$ \\
$P(T<=t)$ one-tail & 0,413 & 0,000 \\
$t$ Critical one-tail & & 1,650 & 1,650 \\
\hline
\end{tabular}

Tabel 8. Hasil uji T-Test Segmen Ciliwung Hilir

\begin{tabular}{lrrr}
\hline \multicolumn{1}{c}{ Parameter } & BPDAS & \multicolumn{1}{c}{ SRTM } & \multicolumn{1}{c}{ ASTER } \\
\hline Mean & $704.574,815$ & $705.065,584$ & $716.739,504$ \\
Variance & $5.763 .011,327$ & $2.316 .547,151$ & $58.247 .852,520$ \\
Observations & 62,000 & 62,000 & 62,000 \\
Pooled variance & & $4.039 .779,239$ & $32.005 .431,930$ \\
Hypothesized mean difference & & 0,000 & 0,000 \\
df & & 122,000 & 122,000 \\
$t$ Stat & & $-1,360$ & $-11,972$ \\
$P(T<=t)$ one-tail & 0,088 & 0,000 \\
$t$ Critical one-tail & & 1,657 & 1,657 \\
\hline
\end{tabular}

yang dihasilkan dari DEM dan peta acuan. Semakin ke area hilir dimana kemiringan lahan semakin datar perbedaan batas deliniasi yang dihasilkan oleh DEM semakin terlihat dibandingkan dengan data peta acuan, terutama pada batas yang dihasilkan oleh DEM ASTERGDEM. Hasil ini mendekati hasil-hasil penelitian terdahulu yang dilakukan di lokasi maupun dengan metode yang berbeda, sebagai contoh penelitian yang dilakukan oleh Pryde, et al (2007) dengan judul "Comparison of watershed boundaries derived from SRTM and ASTER digital elevation datasets and from a digitized topographic map" yang dilakukan di Daerah Aliran Sungai Rio Chimbo, Ekuador menunjukkan hasil deliniasi yang dihasilkan dari DEM SRTM dan ASTERGDEM tidak memiliki perbedaan yang signifikan terhadap peta acuannya.

Sedangkan pada area di sebelah barat yang memiliki kemiringan lahan paling landai menunjukkan terjadi perbedaan yang cukup besar pada batas deliniasi yang dihasilkan oleh DEM ASTER-GDEM terhadap peta acuannya. Hal ini dapat dilihat berdasarkan hasil regresi linier dari kedua data dimana pada bagian hulu kedua data menghasilkan nilai $\mathrm{R}^{2}=0,99$ sedangkan pada segmen barat ASTER-GDEM hanya menghasilkan nilai $\mathrm{R}^{2}$ sebesar 0,88 dan DEM SRTM sebesar 0,99. Berdasarkan penelitian tersebut diketahui bahwa terjadinya perbedaan ini dimungkinkan karena adanya error dalam penentuan arah aliran (flow stream) yang disebabkan oleh kesalahan dalam file DEM ASTER-GDEM yang menyebabkan operasi algoritma yang dijalankan program menghasilkan output yang salah.

\section{Kesimpulan}

Berdasarkan penelitian yang telah dilakukan dengan membandingkan hasil pemodelan daerah aliran sungai menggunakan data DEM ASTER GDEM dan SRTM serta peta daerah aliran sungai Ciliwung yang diperoleh dari BPDAS Ciliwung- 
Citarum, maka kesimpulan yang dapat diperoleh dari penelitian ini adalah data digital elevation model (DEM) dapat digunakan sebagai bahan pemodelan peta daerah aliran sungai.

Hasil modeling dengan data DEM SRTM menghasilkan luasan 5\% lebih kecil dibandingkan dengan peta DAS Ciliwung yang diperoleh dari BPDAS, sedangkan hasil modeling dengan ASTER-GDEM menghasilkan luasan $87 \%$ lebih besar. DEM SRTM memiliki tingkat akurasi yang lebih baik $(\mathrm{R} 2=0,99)$ dibandingkan dengan DEM ASTER-GDEM $(\mathrm{R} 2=0,47)$ dalam pemodelan DAS Ciliwung.

Dari ketiga segmen DAS yang diuji menghasilkan daerah hulu (kemiringan lereng $\gg 15 \%$ ) yang berada di daerah pegunungan memiliki nilai akurasi paling tinggi. Sedangkan daerah hilir (kemiringan lereng $\ll 8 \%$ ) yang berada di daerah dataran rendah dan landai menunjukkan akurasi yang kurang baik, terutama pada ASTER-GDEM.

Dapat disimpulkan bahwa penggunaan data DEM SRTM dan ASTER GDEM memiliki tingkat akurasi yang baik dalam pembuatan model Daerah Aliran Sungai pada area yang memiliki kemiringan lereng lebih besar dari $8 \%$.

Di samping dari adanya error atau kekurangan pada peta yang dihasilkan, penggunaan data DEM dalam pembuatan delineasi DAS sangat membantu dalam proses pemetaan karena mampu memetakan area yang luas dengan cepat dan mudah tanpa perlu mengeluarkan tenaga dan biaya ekstra.

\section{Daftar Pustaka}

Bodis, K. (2008). Digital Elevation Model and Their Applications in Flood Risk Management, PhD Thesis, Hungaria: University of Szeged.

Du, X., Guo, H., Fan, X., Zhu, J., Yan, Z., \& Zhan, Q. (2012). Vertical Accuracy Assessment of SRTM and ASTER GDEM Over Coastal Regions of China : a Comparative Analysis. Paper presented at the 33rd Asisan Conference on Remote Sensing (pp. 1 - 2), Asian Assocition on Remote Sensing, Pattaya, Thailand.

Kumthekar, M. B., Shinde, V. M., \& Deshpande, P. K. (2013). Application of ASTER DEM in Watershed Management as Flood Zonation Mapping in Koyana River of the Western Ghats. IJSER, 4(5), 297 - 301.

Leitão, J. P., Moy, D. V. M., Scheidegger, A., \& Rieckermann, J. (2016). Assessing the Quality of Digital Elevation Models Obtained from Mini
Unmanned Aerial Vehicles for Overland Flow Modelling in Urban Sreas. Hydrology and Earth System Sciences, 20(4), 1637-1653.

Manikpuri, M. M., \& Choudhary, S. (2013). Pour Point Description Of Watershed Based On DEM Of Bilaspur District. International Journal of Advanced Computer Research, 3(3), 197.

Nugraha, A. L. (2013). Kajian Pemanfaatan Dem Srtm \& Google Earth untuk Parameter Penilaian Potensi Kerugian Ekonomi Akibat Banjir Rob. Teknik, 34(3), 202-210.

Pryde, J. K., Osorio, J., Wolfe, M. L., Heatwole, C., Benham, B., \& Cardenas, A. (2007). Comparison of watershed boundaries derived from SRTM and ASTER digital elevation datasets and from a digitized topographic map. Paper presented at ASABE Annual International Meeting (Paper Number : 072093), American Society of Agricultur and Biological Engineers, Minneapolis, Minnesota.

Riyanto, I., \& Sudiana, D. (2009). Pemetaan Daerah Potensi Banjir dengan Segmentasi Data Digital Elevation Model Studi Kasus: DAS Ciliwung di DKI Jakarta 2007, PhD Thesis, Indonesia: Universitas Indonesia.

van de Kwast, H. (2017). Exercise open source software for preprocessing GIS data for hydrological models. Delf: UNESCO IHE Open Course.

van de Sande, B., Lansen, J., \& Hoyng, C. (2012). Sensitivity of Coastal Flood Risk Assessments to Digital Elevation Models. Water, 4(3), 568-579

Suwandana, E., Kawamura, K., Sakuno, Y., Kustiyanto, E., \& Raharjo, B. (2012). Evaluation of ASTER GDEM2 in Comparison with GDEM1, SRTM DEM and Topographic-map-derived DEM using Inundation Area Analysis and RTK-dGPS Data. Remote Sensing, 4(8), 2419-2431.

Valeriano, M. M., Kuplich, T. M., Storino, M., Amaral, B. D., Mendes Jr, J. N., \& Lima, D. J. (2006). Modeling Small Watersheds in Brazilian Amazonia with Shuttle Radar Topographic Mission-90 m Data. Computers and Geosciences, 32(8), 1169-1181.

Yulianto, F., \& Marfai, M. A. (2010). Model Simulasi Luapan Banjir Sungai Ciliwung di Wilayah Kampung Melayu Bukit Duri Jakarta, Indonesia. Jurnal Penginderaan Jauh dan Pengolahan Data Citra Digital, 6(2009), 43 - 53. 